\title{
FÉMHABSTRUKTÚRA ELEMZÉSE CT FELVÉTELEK ALAPJÁN
}

\section{STRUCTURAL ANALYSIS OF METAL FOAMS WITH COMPUTED TOMOGRAPHY}

\author{
Varga Tamás Antal ${ }^{1}$, Budai István ${ }^{2}$, Gábora András ${ }^{3}$, Kozma István ${ }^{4}$, Manó Sándor ${ }^{5}$, \\ Mankovits Tamás ${ }^{6}$ \\ IDebreceni Egyetem, Müszaki Kar, Gépészmérnöki Tanszék, 4028, Magyarország, \\ Debrecen, Ótemető utca, 2-4; Telefon: +36-52-415-155/77780, var- \\ ga.tamas@eng.unideb.hu \\ ${ }^{2}$ Debreceni Egyetem, Müszaki Kar, Müszaki Menedzsment és Vállalkozási Tanszék, \\ 4028, Magyarország, Debrecen, Ótemetö utca, 2-4, budai.istvan@eng.unideb.hu \\ ${ }^{3}$ Debreceni Egyetem, Müszaki Kar, Gépészmérnöki Tanszék, 4028, Magyarország, \\ Debrecen, Ótemetö utca, 2-4, andrasgabora@eng.unideb.hu \\ ${ }^{4}$ Széchenyi István Egyetem, Müszaki Tudományi Kar, Anyagtudományi és Technoló- \\ giai Tanszék, 9026, Magyarország, Györ, Egyetem tér 1, kozma@sze.hu \\ ${ }^{5}$ Debreceni Egyetem, Ortopédiai Klinika, 4028, Magyarország, Debrecen, Nagyer- \\ deikörút98,manos@med.unideb.hu \\ ${ }^{6}$ Debreceni Egyetem, Müszaki Kar, Gépészmérnöki Tanszék, 4028, Magyarország, \\ Debrecen, Otemetö utca, 2-4, tamas.mankovits@eng.unideb.hu
}

\begin{abstract}
The development of an efficient procedure for 3D modelling and finite element simulation of metal foams is one of the greatest challenges to engineer researchers nowadays. Creating 3D CAD model from its structure is alone a demanding engineering task due to its extremely complex geometry, and the proper finite element analysis process is still in the center of the research. In this paper the evaluation of the records of the X-ray computed tomography inspection is introduced for the investigated specimen.
\end{abstract}

Keywords: metal foam, modeling, computed tomography, volume analysis

\section{Összefoglalás}

A mérnöki kutatások egyik nagy kihívása a mára már széles körben alkalmazott fémhabok geometriai modellezése, valamint a megalkotott 3D-s modell numerikus szilárdságtani vizsgálata. A fémhab struktúrája meglehetősen bonyolult, így a valóságot jól megközelítő CAD modell előállítása önmagában is komoly mérnöki feladat, annak adott terhelésre történő véges elemes szimulációja pedig a kutatások középpontjában áll. A projekt ezen részének célja, hogy a próbatestekről készített CT felvételek alapján elemezzük a belső cellák térfogatát.

Kulcsszavak: fémhab, modellezés, CT, térfogatelemzés 


\section{Bevezető}

A fémhab viszonylag régóta ismert, de ipari és orvosi alkalmazása csak az elmúlt pár évben kezdett széles körben elterjedni. Ez annak köszönhető, hogy mára már megbízható eljárások léteznek a gyártási technológiára, amely technológia eredményeképpen szabályozható az előállitásra kerülő fémhab belső szerkezete. Köztudott, hogy a fémhaboknak kicsi a sürüsége, de ennek ellenére kiváló mechanikai és fizikai tulajdonságokkal rendelkeznek [1-3]. Emellett számos olyan pozitív tulajdonságuk van, amelynek eredményeként nemcsak rezgés-, vagy ütközéscsillapításra alkalmasak, hanem teherviselő elemként (járműalkatrészként, protézisként) is kiválóan helytállnak [4-9]. Ezek a területek, leginkább teherviselő anyagként alkalmazzák a fémhabokat, ezért azt várjuk, hogy az alkalmazás során rugalmasan viselkedjen, így megfelelő biztonsággal kell ismernünk, vagy képeseknek kell lennünk megbecsülni az anyagunk válaszát az adott terhelésre. Annak érdekében, hogy egy geometriai modellt tudjunk elöállítani a fémhabról, ami egy komoly mérnöki feladat, kellő információval kell rendelkeznünk annak a belső szerkezetéről [10]. A fémhabok fizikai és mechanikai tulajdonságai közvetlenül függnek a fémhab struktúrájától és sztochasztikus jellegétől. Mivel a fémhabok belső szerkezete meglehetősen bonyolult, így felületelemzéssel csak hiányos, sok esetben pedig félrevezető információhoz juthatunk.

Jelenleg leghatékonyabban CT berendezéssel lehet meghatározni a fémhabok belső struktúráját. Ez az eljárás nagyon hatékony, de egyben elég komplex feladatot ad az ebből kidolgozni kívánt modell előállítása. Az eljáráshoz CT berendezésre van szükségünk, amely nem mindig áll rendelkezésre, illetve az ilyenfajta modellalkotásnak komoly számítási igénye van, amelyet egy átlagos teljesítményü számítógép nem ké- pes elvégezni. Kijelenthetö, hogy ez ma a legkorszerübb olyan eljárás, amely segítségével pontos információkhoz juthatunk a vizsgált szerkezetünk belsejéről is. Jelenlegi cikkünkben, bemutatni kívánunk egy újszerủ struktúra elemzési eljárást a fémhab belső szerkezetével kapcsolatban.

\section{CT berendezés müködése}

A CT berendezés az egyedüli méréstechnikai eszköz, amellyel olyan térfogatinformáció szerezhető a vizsgált alkatrészröl, ami nemcsak a külső burkolófelület topológiáját határozza meg nagy pontossággal, hanem adatot szolgáltat a belső struktúráról, inhomogenitásról is [11]. Napjainkban a CT berendezéseket számos vizsgálathoz alkalmazzák. Az egyik legismertebb alkalmazási területi az orvostudomány, de számos müszaki alkalmazási területe van. A CT berendezés $2 \mathrm{D}$-s felvételt készít az adott munkadarabról, majd a munkadarabot az asztallal együtt egy bizonyos szögben elfordítja, és újabb felvételt készít róla (1. ábra). Ez addig folytatódik, amíg az adott munkadarab teljesen körbe nem fordul. Az alkatrész ellentétes oldalán elhelyezett detektor érzékeli a különböző röntgen intenzitást. A vizsgálat elvégzése után rendelkezésünkre áll minden egyes egységnyi szögelfordulás után egy 2D-s kép. A CT berendezés müködési elvét az 1. ábra szemlélteti.

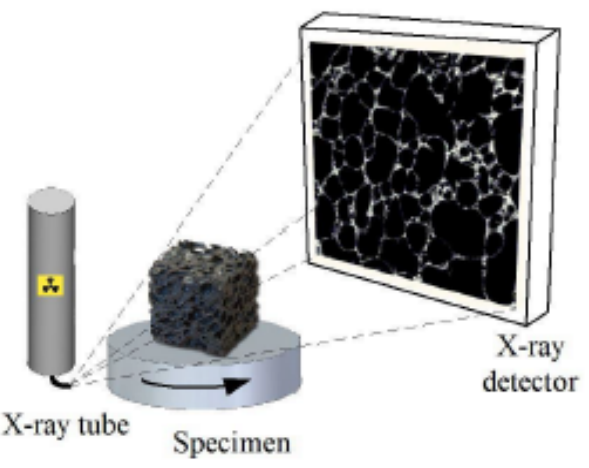

1. ábra. $C T$ berendezés müködése 


\section{Térfogatelemzés CT felvételek alapján}

A CT felvételek alapján a fémhab próbatesteken porozitás vizsgálatot lehet elvégezni egy célszoftver segítségével, amellyel meghatározhatóak a fémhab modelleket felépítő cellák adatai. A kiértékelő szoftverbe a próbatestekröl készült CT felvételek kerülnek importálásra, majd a szoftver ezeket feldolgozza, tehát elmondható, hogy az eredeti CT képekkel dolgozik, azokat nem alakítja át, így az eljárás hitelesnek mondható. Számunkra a következő adatok bizonyulhatnak hasznosnak:

- cella körülírható gömbjének átmérője;

- cella középpontja;

- cella térfogata;

- cella felülete;

- két cella közötti legkisebb távolság;

- cella gömbisége;

- cellát körülírható téglatest méretei.

A szoftver által meghatározott adathalmazból a későbbiekben lehetőségünk nyílik jobban megismerni a fémhabunk struktúráját, és ez a későbbiekben hasznos lehet egy idealizált modell felépítéséhez is. A vizsgálatból látható majd, hogy a fémhabstruktúránk teljesen rendezetlen cellákból állnak. Ez a legfőbb ok, amiért nehéz modellezni a fémhabstruktúrát idealizált modellekkel, és ezért előnyös CT alapú valós modelleket használni, és azokat szimulálni.

A következőekben a vizsgálati eljárás által meghatározott adatokat kívánjuk bemutatni egy próbatesten. Az általunk vizsgált alumíniumhab alapanyaga Al-SiC, amely kelesztéses eljárással lett előállítva. A próbatest mérete 14,5 mm x 14,5 mm x $14,5 \mathrm{~mm}$. A térfogatelemző szoftver a próbatesten 185 cellát detektált, és meghatározta az általunk meghatározni kívánt adatokat. A szoftver csak az $1 \mathrm{~mm} 3$-nél nagyobb cellákat vizsgálta.

\subsection{Cellák térfogatának eloszlása}

A fémhab számos cellából épül fel, amelyek jelen gyártási technológiának köszönhetően nem azonos alakúak és méretüek. Az idealizált modell kialakításához ezekről a cellákról minél több információt kell megtudnunk, hogy komplex képet kapjunk a fémhabunk struktúrájáról. A térfogatelemző szoftverünk segítségével lehetőségünk van ezeknek a celláknak a térfogatát meghatározni. A 2. ábrán láthatjuk a fémhabot felépítő cellák térfogateloszlását.

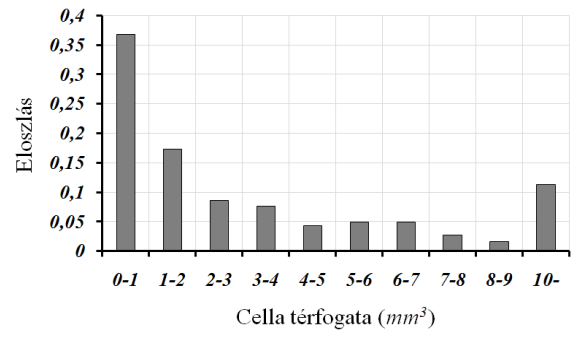

2. ábra. Cellák térfogatának eloszlása

\subsection{Cellaátmérők eloszlása}

A térfogatelemző szoftver képes meghatározni a cellát körülíró kör átmérőjének nagyságát meghatározni. Ez az átmérő egyben az cella két legszélsőbb pontjának távolsága. Ezeknek az átmérőknek az eloszlását a 3. ábrán láthatjuk.

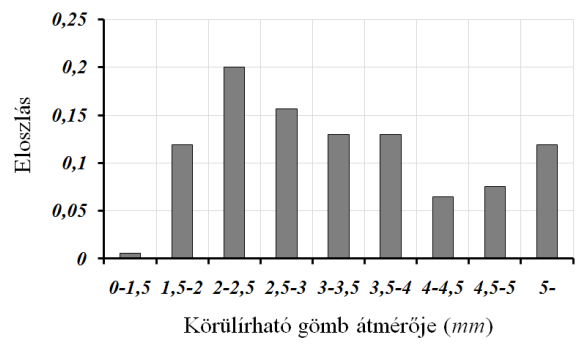

3. ábra. Cellát körülíró gömb átmérői

\subsection{Cellák gömbisége}

A fémhabunkban lévő cellák nem szabályosak így érdemes megvizsgálni ezeknek gömbiségét. A gömbiség egy arányszám, amely annak az értéke, hogyan aránylik az 
cella térfogata a cellát körülíró gömb térfogatához. Ezzel megkapjuk, hogy az általunk vizsgált cellák mennyire szabályosak (4. ábra).

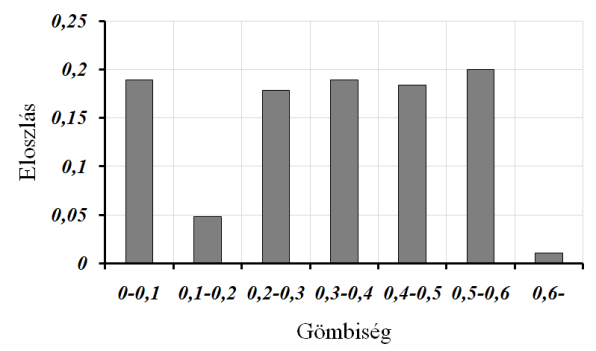

4. ábra. Cellák gömbiségének eloszlása

\section{4. Összefoglalás}

A CT felvételek alapján megvizsgáltuk a fémhab belső struktúráját és elemeztük azt. A vizsgálat során meghatároztuk a fémhab celláinak nagyságát, elhelyezkedését. A vizsgálat során arra a következtetésre jutottunk, hogy a fémhabot felépítő cellák nem szabályos gömb alakúak, így a modell geometriáját nehezen lehet gömb elemekből felépíteni.

\section{Köszönetnyilvánítás}

A publikáció elkészítését az Emberi Erőforrások Minisztériuma megbízásából az Emberi Erőforrás Támogatáskezelő által 2015-ben meghirdetett „Egyedi fejlesztést biztosító ösztöndíjak" (NTP-EFÖ-P-15) címü pályázati kiírása alapján a Nemzeti Tehetség Program támogatta.

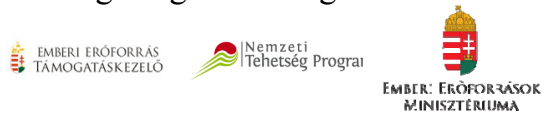

\section{Szakirodalmi hivatkozás}

[1] Ashby, M.F., Evan, A.G., Fleck, N.A., Gibson, L.J., Hutchinson, J.W., Wadley, H.N.G: Metal Foams: A Design Guide. ButterworthHeinemann, 2000.
[2] Czekanski, A., Attia, M.S., Meguid, S.A., Elbestawi, M.A: On the Use of a New Cell to Model Geometric Asymmetry of Metallic Foams. Finite Elements in Analysis and Design, 41(13), 1327-1340, 2005.

[3] Banhart, J: Manufacture, Characterization and Application of Cellular Metals and Metal Foams. Progress In Materials Science, 46(6), 559-632, 2001.

[4] Vendra, L.J., Rabiei, A: Evaluation of Modulus of Elasticity of Composite Metal Foams by Experimental and Numerical Techniques. Materials Science and Engineering: A, 527(78), 1784-1790, 2007.

[5] Tuncer, N., Arslan, G: Designing Compressive Properties of Titanium Foams. Journal of Materials Science, 44(6), 1477-1484, 2009.

[6] Kádár, Cs., Chmelík, F., Rajkovits, Zs., Lendvai, J: Acoustic Emission Measurements on Metal Foams. Journal of Alloys and Compounds, 378(1-2), 145-150, 2004.

[7]Djebbar, N., Serier, B., Bouiadjra, B.B., Benbarek, S., Drai, A: Analysis of the Effect of Load Direction on the Stress Distribution in Dental Implant. Materials\&Design, 31(4), 2097-2101, 2010.

[8] Kashef, S., Asgari, A., Hilditch, T.B., Yan, W., Goel, V.K., Hodgson, P.D: Fracture Toughness of Titanium Foams for Medical Applications. Materials Science and Engineering: A, 527(29-30), 7689-7693, 2010.

[9] Mankovits, T., Tóth, L., Manó, S., Csernátony, Z: Mechanical Properties of Titanium Foams, a Review. Proceedings of the 1st International Scientific Conference on Advances in Mechanical Engineering, 10-11 October, Debrecen, Hungary, 2013.

[10] Saadatfar, M., Mukherjee, M., Madadi, M., Schröder-Turk, G.E., Garcia-Moreno, F., Schaller, F.M., Hutzler, S., Sheppard, A.P., Banhart, J., Ramamurty, U: Structure and Deformation Correlation of Closed-cell Aluminium Foam Subject to Uniaxial Compresion. Acta Materiala, 60(8), 3604-3615, 2012.

[11] Kozma, I: A komputertomográf ipari alkalmazásai. A jövő járműve jármüipari innováció, Volume 5/3-4, Györ, Hungary, 2006, 811. 